\title{
Refugiados do Holocausto em Portugal: representações da "vida nua" no corpo social português
}

Resumo:

Este artigo versa sobre as representações da passagem de refugiados do Holocausto por solo português na trilogia O cavalo espantado (1960) de Alves Redol, Sob céus estranhos (1962) de Ilse Losa e Sob céus estranhos: uma história de exílio (2007) de Daniel Blaufuks. Sob três perspectivas narrativas distintas - aquela do "Justo entre as Nações", a do próprio refugiado e a do herdeiro dessa "pós-memória" (Hirsch 1992-1993) - esses autores retratam a presença dessas "vidas nuas" (Agamben 1997) no corpo social português. Na sua condição de fora-da-lei, o refugiado torna-se uma figura privilegiada para colocar em causa a "ficção originária da soberania" (Agamben 2002: 32). Pretendemos analisar, ainda, como a figura do refugiado suscita reflexões sobre o ser português, através de duas tipologias imagológicas: a "ideológica" e a "utópica" (Moura 1998).

Palavras-chave:

Holocausto, refugiado, judeu, Alves Redol, Ilse Losa, Daniel Blaufuks

\section{Abstract:}

This article deals with the representations of the passage of Holocaust refugees through Portuguese soil in the trilogy O cavalo espantado (1960) by Alves Redol, Sob céus estranhos (1962) by Ilse Losa and Sob céus estranhos: uma história de exílio (2007) by Daniel Blaufuks. Under three distinct narrative perspectives - that of "Just among the Nations", that of the refugee himself and that of the "post-memory's" heir (Hirsch 1992-1993) - these authors portray 1997) in the Portuguese social body. In his condition as an outlaw, the refugee becomes a privileged figure to question the "fiction originating from sovereignty" (Agamben 2002: 32). We also intend to analyze how the figure of the refugee raises reflections on the Portuguese identity, through two types of images: the "ideological" and the "utopian" (Moura 1998).

Keywords:

Holocaust, refugee, Jew, Alves Redol, Ilse Losa, Daniel Blaufuks 


\section{Introdução}

A presença de refugiados judeus em solo português durante os anos 30 e $40^{1}$ tem despertado, nas últimas três décadas, o interesse crescente de historiadores de diversas nacionalidades, focados tanto no papel de Portugal como país de passagem na rota de fuga das vítimas diretas e indiretas do Holocausto, quanto na sua ambígua posição de neutralidade durante a Segunda Guerra Mundial (Mühlen 1992; Schäfer 1992; Afonso 1995; Milgram 1999; Pimentel 2006; Lochery 2011; Ninhos/Pimentel 2013; Meneses 2015; Ninhos 2017). O discurso do Estado Novo salazarista perante o "indesejável" foi igualmente analisado em estudos na área de Sociologia (Maranhão 2006; Chalante 2011; o primeiro numa abordagem comparativa com o regime político homônimo de Getúlio Vargas, no Brasil). Segundo Irene F. Pimentel, no início dessa trajetória de pesquisa socio-histórica, encontram-se os textos literários da escritora portuguesa de origem judaico-alemã, Ilse Losa. Perseguida pela Guestapo, Losa abandona a Alemanha natal para instalar-se, em 1934, na cidade do Porto, onde se fez escritora escrevendo em português, traduzindo-se ou, na maioria das vezes, fazendo-se traduzir para a sua língua materna. Essa história de vida é representada nos seus romances autobiográficos 0 mundo em que vivi (1949) e Sob céus estranhos (1962), cuja importância no panorama literário europeu é assim avaliada por Jochen Vogt: "pela perspectiva verdadeiramente intercultural, estes livros merecem lugar de destaque na literatura de exílio europeia" (Vogt 2019: 14). A essas obras Vogt teve acesso na sua versão alemã, apenas no início dos anos 90, quando a escritora publicou uma parte importante da sua produção. ${ }^{2}$

Podemos observar, portanto, que se o tema do Holocausto teve o seu tempo de maturação pela sociedade alemã, ele não foi tampouco imediatamente estudado por pesquisadores portugueses. Pimentel assim explica as razões que motivaram o despertar de interesse tardio dos portugueses sobre esse assunto, realçando o papel da obra loseana nesse percurso:

Por várias razões a memória da presença dos refugiados em Portugal, durante os anos 30 e a II Guerra Mundial, permaneceu escondida até ao final dos anos 80 do século XX. Durante o período da ditadura, o próprio regime salazarista submergiu essa memória e tornou impossível fazer história do período contemporâneo próximo. Por outro lado, após o 25 de abril, houve no campo da historiografia muitas outras prioridades. Tudo estava por fazer, desde a caracterização do regime até o estudo das suas instituições. E o tema dos refugiados dos anos 30-40 do século XX era apenas um pequeno episódio da história do Estado Novo. [...] Em 1989, a escritora e socióloga alemã Christa Heinrich começou a procurar pistas e bibliografias sobre a passagem de refugiados por Portugal. Na Alemanha, apenas tinha encontrado os romances de Ilse Losa e algumas pequenas recordações de escritores que tinham passado por Portugal enquanto refugiados durante a II Guerra Mundial. (Pimentel 2006: 18-19)

Se os laços de Ilse Losa com a língua e a cultura alemãs facilitaram o acesso aos seus romances por pesquisadores germânicos em busca de compreensão sobre o seu passado nacional, muitos outros textos literários de escritores portugueses e estrangeiros trazem-nos representações 
desse período histórico e da passagem de refugiados judeus por terras lusitanas, permitindo-nos um estudo imagológico do ser português em contraste com a alteridade paradoxal do refugiado: figura carregada de referenciais identitários étnicos, religiosos e nacionais e, simultaneamente, desprovida de pertença legal a qualquer Estado-Nação.

Giorgio Agamben, baseado no conceito foucaultiano de biopoder, coloca em evidência os laços íntimos que ligam a vida humana à construção da identidade nacional: "Estado-Nação significa: Estado que faz da natividade, do nascimento (quer dizer, da pura e simples vida humana) o fundamento da sua soberania"3 (Agamben 2002: 31). Na condição predominante de apátridas, esses refugiados são "vidas nuas" [vies nues] (Agamben 1997: 15), excluídas de proteção jurídica e submetidas tanto ao biopoder do Estado de origem, quanto àquele do Estado de acolhimento, no qual passam a representar um elemento inquietante. Assim, a figura do refugiado associa-se àquela do homo sacer, o "homem sagrado" do direito romano arcaico, legado à sua própria sorte (ou ao capricho dos deuses), já que banido tanto da lei divina quanto humana. Ser impróprio ao sacrifício, mas cujo assassinato, paradoxalmente, não é passível de condenação.

Dentre as obras literárias que melhor representam a passagem dessas "vidas nuas" (Agamben 2002: 31) por solo português, durante o período da Segunda Guerra Mundial, e que mais material nos fornecem para uma análise imagológica do encontro entre portugueses e refugiados, estão O cavalo espantado (1960) de Alves Redol, Sob céus estranhos (1962) de Ilse Losa e Sob céus estranhos: uma história de exílio (2007) de Daniel Blaufuks.

No romance de Alves Redol (1911-1969), o protagonista Pedro Osório, português, é funcionário do consulado da Argentina em Lisboa e escritor amador. Ele decide conceder vistos de saída do território português a um casal de judeus autríacos, Leo e Jadwiga, portadores de passaportes argentinos falsos:

Como todos os outros, era um desses passaportes marcados com um J na primeira folha, sinal de que o portador era judeu. Esse estigma só servia, afinal, para que Pedro tomasse a obrigação de os ajudar. Tinha ali à mão o destino de muitos homens. Podia recusar a formalidade, podia facilitá-la. [...] chegara um ofício do Ministério dos Negócios Estrangeiros a dizer que não deviam conceder mais vistos a judeus. Sentiu a fragilidade da noção de justiça em tempos perturbados como os que se viviam. (Redol 60: 22)

Essa postura ética não é tomada sem a existência de um conflito interno no personagem, já que Pedro precisa enfrentar, para além do medo de perder o emprego e do desacato às autoridades portuguesas, o aliciamento financeiro de Leo e o amor secreto por Jadwiga. É importante realçar que, segundo Ana Paula Ferreira, "Alves Redol foi um desses portugueses que, exercendo as funções de vice-cônsul do Paraguai na Procuradoria Geral dos Municípios, passou vistos a judeus lá acorridos, sendo 0 cavalo espantado baseado em factos concretos dessa sua experiência de vida" (Ferreira 2012: 62). 
Cadernos de Literatura Comparada

Refugiados do Holocausto em Portugal

No romance de pendor autobiográfico da escritora portuguesa de origem judaico-alemã, Ilse Losa (1913-2006), temos a figura do refugiado judeu-alemão Josef Berger, que se torna o "José" em Portugal. Tanto a autora quanto o personagem chegam a terras lusitanas antes da eclosão da guerra, casando-se com cidadãos portugueses e assumindo o papel de "tradutores culturais" (Hall 2008: 396) entre portugueses e refugiados. Apesar da oportunidade de se reconstruir em terra de exílio, Josef é ainda habitado pela violência nazi: "seria outro se não soubesse do massacre de inocentes que meus compatriotas levaram a cabo [...] a sua brutalidade vive em mim, viverá sempre em mim" (Losa 1984: 17).

O título da obra de Daniel Blaufuks (1963-) remete-nos àquele do romance de Losa, acrescentando-lhe um percurso pessoal: Sob céus estranhos: uma história de exílio. No livro do fotógrafo-escritor, essa intertextualidade é afirmada ao leitor, demonstrando o desejo de uma leitura dialógica das duas obras: "o título Sob céus estranhos é retirado de um livro de Ilse Losa, que chegou a Portugal em 1934 e aqui faleceu em 2006" (Blaufuks 2007: s/p). Blaufuks narra a sua própria história de vida enquanto neto de refugiados judeus instalados em Lisboa: alemães pelo lado materno e polacos, pelo paterno. Estão inseridos na narrativa de vida de Blaufuks uma somatória de relatos verbais e não verbais de seus avós Ursel e Herbert August, vítimas indiretas do Holocausto, refugiados em Lisboa em 1936, assim como aqueles de outros refugiados. Todos esses coautores têm como ponto comum a passagem por Portugal na sua rota de fuga. Tal diáspora judaica em terras lusitanas é, ainda, contada em som e imagem no CD de 57 minutos que acompanha o livro.

\section{As técnicas narrativas para responder ao dever de memória}

Com relação às técnicas narrativas utilizadas para responder ao dever de memória sobre a passagem de refugiados judeus por Portugal, podemos observar a criação de um espaço metaficcional em Redol, instaurado pelo prefácio da obra. Nessa espécie de antecâmara à ação romanesca, o escritor "prepara" o leitor, como é indicado no título: "o escritor antecipa-se e fala das personagens antes que outros as encontrem e conheçam" (Redol 2017: 13). Não se trata, no entanto, de um monólogo, mas de um diálogo com o leitor:

Estávamos longe, em 1936, tu e eu, todos nós, de saber que a humana medida chegaria às fezes da demência e da crueldade [...] 1936 foi um ano de complexas opções. E entre todas as da Espanha violentada: 200000 mortos em duas semanas. A guerra civil de ultraje e de esperança, de Campesino e de Picasso (Redol 2017: 14)

O romance de Redol apresenta, portanto, logo à partida, o viés "dialógico" do movimento neorrealista português, do qual Redol foi protagonista com o seu romance Gaibéus; por oposição ao atributo de "ideológico", convencionalmente associado a esse movimento (Ferreira 2018: 61). Através desse prefácio, Redol cria uma "paratopia" [paratopie] (Maingueneau 2004: 52-53), inserindo-se a si e ao leitor num espaço coletivo de enunciação, entre o factual e o ficcional. Nele, entrecruzam-se a grande História da Europa com aquela íntima do personagem, 
Pedro Osório, alter-ego do autor, no seu encontro com "uma coletividade que lhe é estranha e estrangeira, mas cuja tragédia pressiona o imperativo ético de amor ao próximo" (Ferreira 2018: 62). A criação de um personagem permite a Redol um distanciamento com relação aos factos por si mesmo vividos, uma autoanálise:

Conheci Pedro também nessa altura. Era homem taciturno, contraditório [...]. No tempo deste romance, Pedro dominava os instintos com o bridão de uma ética aparentemente revolucionária. [...] A ética de Pedro, sem que ele o suspeitasse, pertencia a tempos muito recuados: à época estável da burguesia vitoriosa e segura. A classe que ele, por ironia, odiava. (Redol 2017: 15)

Por meio não somente deste prólogo, mas também do posfácio em que Pedro conta a sua visita ao gueto de Varsóvia, Redol faz a grande História dos homens preceder e transcender a história particular do romance, não cabendo assim no espaço reduzido da diegese. Por isso, Redol cria essa antecâmara romanesca, na qual faz um flashback histórico que remonta ao ano de 1936, mencionando a Guerra Civil Espanhola e os seus pontos de contacto com a grande guerra que viria a eclodir anos mais tarde. Ele alarga ainda mais, dessa forma, o diálogo coletivo, convidando o leitor, enquanto português, a se questionar sobre a solidariedade demonstrada diante do sofrimento de seu vizinho ibérico. Os personagens do romance também são apresentados pelo escritor de acordo com a postura ética tomada durante esse episódio: Leo "festajara com champagne o avanço na Renânia e a glória da Legião Condor" (Redol 2017: 14); sua mulher, Jadwiga, "esteve em espírito nas brigadas internacionais, mas o dinheiro que já lhe pertencia forneceu munições para o fuzilamanento de seus amigos" (ibidem); Pedro Osório "pensara ir morrer a Madrid, mas ficara na sombra de sua jaula (com raiva, diga-se)" (ibidem). Ou seja, o espaço diegético transforma-se numa segunda chance para esses personagens, de modo a que possam cumprir com o seu dever ético e se transformar humanamente. O Anschluss, a anexação da Áustria à Alemanha nazi, em 1938, marco inicial da diegese, faz com que Pedro tenha na ajuda ao casal austríaco uma oportunidade de fazer valer o seu senso de justiça.

Ao antecipar a apresentação desses três personagens, Redol marca o seu lugar de enunciação "paratópico" e responde ao ímpeto de um dever de memória que parte, primeiramente, do autor, projetando-se inteiramente no universo ficcional. Segundo Jean-François Chiantaretto, para que a escrita pessoal possa contar a história é preciso que uma situação de interlocução seja criada "dando lugar ao outro" (Chiantaretto 2002: 14), implicando "ao mesmo tempo múltiplas pertenças e o solo comum da pertença humana" ${ }^{4}$ (Chiantaretto 2002: contracapa). E é, justamente, esse espaço de interlocução que Redol constrói em 0 cavalo espantado, instaurado a partir do seu prefácio. Redol assegura, assim, a inscrição do testemunho pessoal de seu personagem romanesco, Pedro Osório, ou seja, de sua experiência pessoal ficcionalizada, na grande história do Holocausto e na história de Portugal durante esse período.

O romance loseano começa in media res com o refugiado judeu-alemão, Josef Berger, na sala de espera de um hospital, na cidade do Porto. Nele, sua esposa, Teresa, portuguesa, está prestes a dar à luz ao primeiro filho do casal. Esse espaço fechado, no qual vida e morte cohabitam e um 
Cadernos de Literatura Comparada

Refugiados do Holocausto em Portugal

sentimento de impotência domina os seres, pode ser compreendido como um "cronotopo" [chronotope] (Bakhtin 1978: 235) que opera a fusão entre a terra natal e a terra de exílio do protagonista. Uma sensação de eterno retorno domina o romance, pois o sentimento de opressão associado ao passado na sociedade nazi é reatualizado na sociedade salazarista. Isso pode ser observado pelo retrato com a imagem do presidente do Estado Novo português da época, Óscar Carmona, descrito como um homem "de cara empertigada, de colarinho empertigado, de bigode à Kaiser" (Losa 1984: 7-8).

Em Redol, a instância autoral destaca-se do espaço romanesco, dirigindo-se diretamente ao leitor, de forma a assegurar a inserção da ação de Pedro Osório na grande memória coletiva da Segunda Guerra Mundial. Em Losa, temos o caminho inverso, adentramos mais a fundo no espaço romanesco, num segundo grau diegético, de subconsciência narrativa. É por meio deste adentrar nas "memórias subterrâneas" de Josef (Pollak 1993: 18), alter-ego masculino da autora, que se dá a conexão entre o particular e o universal, a memória individual e a coletiva:

José esperou pelo novo salto do grosso ponteiro prateado. Onde tinha lido que o tempo passava devagar quando espiávamos? [...] Mas na realidade - por que havia sempre além de todas as sensações uma realidade - o tempo não voa de facto? Não voa como uma ave sem destino? Não tinha voado desde o dia em que..../.... eu percorria de bicicleta a paisagem e me maravilhava com as macieiras em flor ao longo da estrada? De repente senti-me tombado no chão. Corpos atiraram-se sobre o meu corpo: mãos abertas, punhos, unhas, botas. A volúpia de homens transformados em bestas: "Espicha, porco de judeu!" (Losa 1984: 31)

Assim como o prefácio metaficcional de Redol, a sala de hospital no romance loseano funciona como uma antecâmara à ação romanesca, marcada pela passagem da narração em terceira pessoa para a enunciação direta do protagonista em primeira pessoa, sob a forma de um fluxo de consciência. O tempo deixa, portanto, em Losa, de ser cronológico para ser psicanalítico, de forma a realçar a interrupção e a fragmentação que o Holocausto causou na trajetória de vida de suas vítimas. Assim, inversamente a Redol, Losa prefere ater-se ao universo romanesco, dando voz a seu protagonista para, através de seus relatos pessoais, oferecer um enquadramento histórico ao leitor. Ao relembrar a cena de violência provocada pelos agentes nazis, Josef volta a sentir o peso real e simbólico daqueles corpos sobre o seu. É uma imagem pungente da força opressora do Estado transformando bios em zoé, e a reação de resistência de Josef no sentido de reverter esse olhar, realçando o retrocesso de uma nação ao estado de selvageria. A história oficial, seria, portanto, construída sobre uma relação de biopoder.

A fronteira entre o biográfico e o ficcional não se coloca na obra de Blaufuks, construída por um pacto autobiográfico estabelecido com o leitor desde a primeira página, a partir de um "passeio entre as campas do cemitério judaico em Lisboa" (Blaufuks 2007: s/p). Sua narrativa de vida é, portanto, de caráter "pós-memorial" [post-memorial/post-memory] (Hirsch 1992-1993: 9): "Lembro-me de/a minha mãe me contar/ de como a sua mãe lhe contou/uma recordação dos tempos de guerra" (Blaufuks 2007: s/p). Blaufuks utiliza-se de hipotextos em 
linguagens e gêneros discursivos diversos para contar uma história que, apesar de ser aquela de sua vida, não lhe pertence exclusiva e inteiramente. Podemos chamar, assim, a obra de Blaufuks de uma "autobiografia pós-memorial". Nela temos, nos termos de Hirsch: "outras 'postagens' e o seu intervalo de tempo, alinhando-se à prática de citação e mediação que as caracteriza [...] oscilação incômoda entre continuidade e ruptura." ${ }_{5}$ (Hirsch 2008: 106).

O formato de álbum multimídia valoriza a polifonia contida na narrativa de vida de Blaufuks. Nele, a fotografia funciona como "elemento aglutinador" (Seixas s/d: s/p), segundo depoimento do autor em entrevista dada a Maria João Seixas. A fotografia está no cerne da reflexão hirsheana sobre a "pós-memória", por ser um "lugar de memória" [lieu de mémoire] (Nora 1984: XXIII), "com a vida e a morte, com o tempo e a eternidade, envolvidos numa faixa de Moebios do coletivo e do individual"6 (Hirsch 1992: 8).

Essa "autobiografia pós-memorial" pode ser, portanto, representada por uma longa faixa de Moebios que contém o percurso de exílio dos refugiados do Holocausto de passagem por Portugal e na qual a vida do autor também se inscreve. A sensação de estranhamento que a interferência dessas vozes em língua alemã provoca no leitor/ouvinte português parece ser uma estratégia criada pelo autor para invocar a presença desses seres, restituindo a legitimidade de seus testemunhos. No entanto, no caso do Holocausto, o testemunho é, por si mesmo, impostura, no que Agamben propõe o conceito de "resto": "o resto de Auschwitz - as testemunhas - não são nem os mortos, nem os sobreviventes [...] mas o que resta entre eles [...] significa precisamente a impossibilidade de coincidir para o todo e para a parte"7 (Agamben 1992: 178).

O livro de Blaufuks - e, por conseguinte, a sua própria vida - é, portanto, uma obra de restos. Por essa razão, a sua autobiografia é, paradoxalmente, um projeto de construção autoral coletiva, ainda que o seu nome figure sozinho na capa do livro como reabilitador de todas essas vozes. Nela, Blaufuks restitui, em primeira pessoa, a propriedade narrativa de cada testemunha citada, ou seja, de cada coautor, cujo nome, texto, voz e, por vezes, imagem, criam um corpo enunciativo pleno.

Surpreende-nos, no entanto, o silêncio do governo português e da imprensa nacional face à passagem desses refugiados por Portugal. O livro de Blaufuks recolhe provas factuais do controle velado ou da rejeição desses corpos individuais pelo grande corpo estatal: um relatório de entradas e saídas emitido pela PVDE (Polícia de Vigilância e Defesa do Estado, 1933-1945); um pedido de visto de entrada indeferido e até um telegrama da prisão de Aljube enviado por um refugiado. O silêncio da imprensa sobre as ações de Hitler é ilustrado por recortes de jornais da época que relatam assuntos banais, enquanto milhares de pessoas eram mortas ou forçadas a emigrar. A esse respeito, Filipe Meneses explica que "não eram somente os censores portugueses que supervisionavam a imprensa; a legação alemã estudava de perto cada linha escrita a fim de assegurar que ela não continha nenhuma crítica sobre a ocupação"8 (Meneses 2015: 9).

Além de uma supervisão severa da imprensa e de um controle rigoroso dos estrangeiros na fronteira espanhola e no interior do território nacional, a propaganda do regime salazarista contribuía à criação de uma falsa imagem de neutralidade de Portugal. Nos primeiros minutos do CD que acompanha o livro, a posição ambígua do país é realçada através do vídeo da primeira 
Cadernos de Literatura Comparada

Refugiados do Holocausto em Portugal

edição de 0 jornal português, ${ }^{9}$ anunciando "a visita do Deutschland", navio de guerra alemão em "visita afetuosa" por Lisboa. Na sequência, vemos "a visita oficial da Home Fleet", "de paz e de amizade", da "velha aliada", trazendo consigo "o penhor de um entendimento secular" (Blaufuks 2007: s/p).

Essa omissão do Estado Novo com relação à questão dos refugiados é confrontada com a imagem pungente das campas do cemitério israelita de Lisboa, instaurando um "lugar de memória" que funciona como o incipit da obra:

Quando passeio entre as campas do cemitério judaico em Lisboa, reconheço os nomes gravados na pedra, como se estivessem num cemitério de aldeia. Uns pertenciam ao círculo mais próximo dos meus avós, ao grupo da canastra, outros iam, como nós, à sinagoga em dias de festa ou ao centro israelita aos sábados à tarde [...] Agora temos três campas neste cemitério. Como muitas outras, pertencem à história desta guerra. (Blaufuks 2007: s/p)

A fotografia do conjunto de lápides no cemitério lisboeta remete, segundo Nascimento e Kirschbaum, tanto ao shtetl, a aldeia judaica ancestral, quanto ao "grupo da canastra", conjunto de amigos refugiados que se reuniam na casa dos avós do autor. Essas lápides são, paradoxalmente, uma prova de sobrevivência, "o testemunho do refúgio em Lisboa" (Nascimento/ Kirschbaum 2019: 18). Constituem, portanto, uma prova irrefutável contra a suposta ausência de Portugal da história da Segunda Guerra Mundial e, por consequência, contra a sua desresponsabilização na política humanitária.

Essa imagem invoca, assim, a presença daqueles seres que ajudarão o autor a contar uma história de sobrevivência partilhada, na qual a vida acolhe a morte: "temos três campas neste cemitério" (Blaufuks 2007: s/p). Temos, portanto, uma imagem fortemente simbólica do trauma transgeracional. Se, para Blaufuks, a imagem do cemitério promove um retorno a um "lugar de memória" afetivo; para Josef, esse regresso é impossível: "imaginara-me vezes sem fim a regressar, caminhar pelas ruas da minha cidade, mas numa cidade onde grassara a morte os ruídos trazem ecos de túmulo [...] e os cheiros ocres e podres evocam cadáveres" (Losa 1984: 172). Vemos, portanto, duas formas distintas de compreensão da morte e de possibilidade do luto, associadas a vivências, espaços e temporalidades diferentes com relação à experiência traumática. Se a terra natal de Blaufuks é ressignificada por dar morada aos corpos dos avós, aquela de Josef carrega ainda as marcas do crime que o impeliu a partir.

Para ambos, essas lápides são o símbolo atroz de uma "pátria cultural" [patrie culturelle] (De Martino 2016: 63) estilhaçada, conceito forjado por Ernesto de Martino para designar o grupo afetivo criado através de um sentimento de pertença coletiva comum, permitindo atribuir à "vida nua" (Agamben 2002: 31), uma dimensão valorizante. De Martino, nos seus estudos sobre a experiência de fim de mundo, afirma que o conceito de mundo é "um conceito cultural, ou seja, inteligível a partir do esforço humano para valorizar a vida"10 (De Martino 2016: 397). Parece-nos, assim, que o diálogo intertextual que Blaufuks tece com a obra loseana tem por objetivo colar os cacos de um mundo comum, de uma "pátria cultural" partilhada. 


\section{O biopoder do estado salazarista e o refugiado entre utopia e ideologia}

Redol retrata Lisboa como um "entroncamento de foragidos e espiões" (Redol 2017: 14) o que corresponde à afirmação de Neill Lochery de que "Lisboa foi, durante a Segunda Guerra Mundial, o centro da espionagem e da intriga internacionais, e a única cidade europeia onde Aliados e potências do Eixo operavam à luz do dia e se vigiavam mutuamente" (Lochery 2011: contracapa). No romance de Redol, Pedro Osório coloca em questão a suposta neutralidade de Portugal, desvendando à Jadwiga, enquanto funcionário consular, os bastidores da diplomacia portuguesa com a Alemanha hitleriana: "- Não sei bem o que se possa entender por um país democrático. Recebemos há dois dias uma ordem que nos interdita de pôr vistos de entrada a judeus. Acha que isso é democracia?" (Redol 2017: 44).

No ano em que se desenrola a intriga do romance, mais precisamente em 28 de outubro de 1938, o governo português emite a circular no 10 pela qual os agentes consulares portugueses eram proibidos de conceder vistos de entrada ao "imigrante sem possibilidade de regressar aos territórios do Reich", ou seja, aos judeus, cujos passaportes eram facilmente identificáveis pela letra "J" neles carimbada. Essa circular foi criada para prevenir a chegada de judeus sem violar um acordo bilateral existente há vários anos entre Portugal e Alemanha. Cada pedido era analisado de forma minuciosa e o máximo que um judeu poderia conseguir era um visto de turismo de 30 dias, o que implicava possuir, além disso, vistos de trânsito pelos países pelos quais passava até chegar a Portugal, um visto de entrada no país de destinação final e fundos para pagar as viagens. Blaufuks assim afima: "todos os vistos concedidos eram para turismo e válidos por períodos de quinze ou trinta dias, teoricamente não renováveis. Assim os refugiados estavam à mercê das autoridades locais." (Blaufuks 2017: s/p).

No contexto da difusão dessa circular, Salazar, então presidente do Conselho de Ministros e Ministro dos Negócios Estrangeiros, assim comenta à margem de um ofício confidencial enviado por Paulo Cumano, inspetor da PVDE: "o judeu estrangeiro é, por norma, moral e politicamente indesejável" (apud Pimentel 2006: 83). A presença do refugiado judeu em solo português era, portanto, vista como uma ameaça à estrutura do Estado Novo salazarista, representada pelo lema: "Deus, pátria, família".

Na obra dos três escritores, a presença de refugiadas judias nos cafés portugueses é o símbolo mais contundente dessa ameaça. Marcadas de um duplo estigma, enquanto estrangeiras e mulheres, elas são completamente desumanizadas, reduzidas à sua sexualidade. Em Redol, vemos "uma montra de pernas e de coxas para todas as gulas lisboetas [...] aquela floresta de carnes expansivas que a esplanada exibia." (Redol 2017: 75). Blaufuks, por sua vez, diz que "Lisboa habituou-se a ver os estrangeiros passarem dias em cafés, que os portugueses não consideravam apropriados para senhoras. As refugiadas fumavam, pintavam os lábios e usavam penteados modernos, que atraíam a atenção dos homens e eram copiados pelas mulheres" (Blaufuks 2007: $\mathrm{s} / \mathrm{p})$. No entanto, as próprias mulheres portuguesas reproduziam a opressão da qual eram vítimas: "as senhoras passavam e fugiam perturbadas de tão escandalosa desvergonha pública" (Losa 1984: 76). Ao analisar Sob céus estranhos, Ana Isabel Marques ressalta a existência de "uma galeria de personagens femininas que povoam o romance e que, independentemente da 
Cadernos de Literatura Comparada

Refugiados do Holocausto em Portugal

idade, estado civil, ou estrato social, se encaixam numa ordem de domínio masculino" (Marques 2019: 58-59).

Ainda no romance loseano, D. Alice, proprietária de uma pensão, recusa-se a hospedar estrangeiras, pois "as mulheres 'lá de fora' eram 'umas desavergonhadas', frequentavam os cafés como se fossem homens." (Losa 1984: 111). Essa personagem reproduz o discurso salazarista, apoiando-se num modelo essencialista de gênero para afirmar a sua superioridade identitária nacional. Em entrevista a António Ferro, Salazar define o que é ser mulher, suas funções e o seu espaço: "Nós devemos [...] deixar o homem lutar pela vida fora do lar, na rua ... E a mulher deve defendê-la, carregá-la em seus braços dentro de casa" (Ferro 2003: 90). Nessa mesma entrevista, ele constrói uma identidade nacional em torno desse biopoder exercido sobre o corpo feminino: "nos países ou nos lugares nos quais a mulher casada faz concorrência ao trabalho do homem - nas usinas, nos ateliês, nos escritórios, nas profissões liberais - a instituição da família para a qual nós lutamos está ameaçada de desabar" (idem: 90).

O discurso de afirmação da superioridade identitária lusitana, expresso na entrevista de Salazar, é construído em torno de um modelo ideal e natural de mulher. Podemos, portanto, perguntar-nos: se, como Benedict Anderson declarou, a nação é uma "comunidade imaginada" [communauté imaginée] (Anderson 1996: 19), o gênero não faria igualmente parte desse imaginário coletivo? Nesse sentido, a identidade nacional, assim como a identidade de gênero, não seria construída com base num modelo natural a seguir? E o gênero, associado ao corpo individual, não seria manipulado politicamente com a finalidade de construir um corpo social, e daí, portanto, uma identidade nacional? (Marques 2017: 97). Possuindo uma atitude de gênero percebida como masculina, as refugiadas abalam a estrutura patriarcal sobre a qual o Estado-Nação português fora construído. Agamben aponta, assim, o refugiado como "um conceito-limite que coloca radicalmente em crise os fundamentos do Estado-Nação, abrindo espaço, simultaneamente, a novas categorias conceituais" ${ }_{11}$ (Agamben 2002: 34). Nesse sentido, Losa retrata a ambivalência de reações provocadas pela presença de refugiados em terras lusitanas:

O desembaraço com que se moviam e agiam, o descuido que manifestavam com relação ao seu arranjo [...] encontravam, para o horror dos habitantes mais velhos, uma série de imitadores na gente nova. Começaram a ver-se raparigas de famílias bem instaladas em simulado négligé de penteado à "refugiada", a fumar cigarros nas confeitarias, a discutir com gestos largos. Rapazes, que até então só saíam à rua com raparigas de sua roda e sempre acompanhadas por mais alguém da família a garantir decência, mostravam-se por toda a parte com as "valdevinas", aparentemente cheias de desprezo pela tranquilidade burguesa. Essa gente estranha, espalhada pelos cafés e pelas praias, a levar uma vida de nómadas, quase de ciganos, destoava do ambiante e criava uma atmosfera de instabilidade, incerteza e angústia. (Losa 1984: 62)

Através deste monólogo interior do protagonista podemos observar a coexistência de duas imagens correspondentes às duas tipologias imagológicas propostas por Jean-Marc Moura 
com base nos estudos de Paul Ricœur: a "ideológica" e a "utópica". Segundo Moura, a ideologia projeta "os valores fundamentais do grupo sobre a alteridade" (Moura 1998: 51), enquanto que a utopia "tem uma função de subversão dos valores do grupo" ${ }^{12}$ (idem: 52). No trecho em questão, os jovens portugueses constroém uma imagem utópica desses estrangeiros, associada à liberdade de movimento e de expressão, por oposição à opressão física e psíquica da sociedade portuguesa salazarista. Escutamos, no entanto, logo em seguida, em discurso indireto livre, a voz dos portugueses mais velhos, que, já formatados por uma "pedagogia nacionalista" [pédagogie nationaliste] (Bhabha 2007: 228), reproduzem o discurso dominante, interpretando como uma ameaça a falta de estabilidade dessas "vidas nuas" (Agamben 2002: 31). A associação aqui feita a outro grupo étnico minoritário, os ciganos, desprendidos com relação aos limites e convenções impostos pelo Estado-Nação, reenvia-nos, incontornavelmente, às ações cometidas pelo partido nazi alemão.

Cabe ao protagonista, portanto, intermediar essas duas imagens antitéticas, situando a figura do refugiado no contexto histórico específico em que se encontra: "os grupos, sempre diferentes e no entanto sempre iguais aos olhos dos que os viam de fora [...] Acontecia chegarem prisioneiros de campos de concentração resgatados por altas somas [...] vinham acabrunhados, esfomeados como bichos, humilhados até à ira ou à apatia." (Losa 1984: 88). Blaufuks, servindo também de "tradutor cultural" (Hall 2008: 396) entre portugueses e refugiados, aponta para a existência de dois sentimentos coletivos, associados a esses mesmos tipos imagológicos: "os fugitivos pareciam levar uma vida inútil, criando assim, entre os portugueses, alguma desconfiança ou mesmo inveja. Não podiam entender quão miseráveis os refugiados se sentiam, cansados desta letargia, desta inércia imposta e sempre preocupados com o que tinham deixado para trás" (Blaufuks 2007: s/p).

Já em Redol, o que domina é a imagem utópica de Jadwiga para Pedro Osório, que já havia se apaixonado por outra refugiada anteriormente: "o seu arrebatamento por Wanda seria, talvez, uma recusa em continuar afundado na cobardia e na resignação. Ela prolongou-se depois em Jadwiga, porque era algo mais do que uma mulher" (Redol 2017: 147). Apesar do amor por essas mulheres, ele decide ficar em Portugal, uma decisão que pode ser compreendida como uma tomada de consciência do seu papel social, um "ato de vingança contra si mesmo" (idem: 15), contra a sua inércia durante a Guerra Civil Espanhola. No prólogo do livro, Redol fala em saber "situar-se num momento de opção. Pedro optou" (ibidem). E, no posfácio da obra, em texto intitulado "rascunho da carta que Pedro nunca enviou a Jadwiga", Pedro Osório confessa à sua amada que ela representou "alguma coisa de essencial" enquanto encarnação da "renúncia" (idem: 287). Tal como o seu amor, essa carta nunca saiu do plano da idealização. Jadwiga foi a utopia necessária para que Pedro vivesse apaixonadamente esses tempos de luta; a alteridade que o possibilitou recusar a conduta social imposta pelo regime; o desejo que o permitia ser português às avessas. 
Cadernos de Literatura Comparada

Refugiados do Holocausto em Portugal

\section{A consciência de Si pelo encontro com o Outro}

Podemos compreender as obras em questão como uma trilogia na qual a consciência de si é despertada pelo encontro com a alteridade radical do refugiado, que "ao quebrar a identidade entre homem e cidadão [...] coloca em crise a ficção originária da soberania"'13 (Agamben 2002: 32). Se toda imagem é falsa enquanto representação, aquela do refugiado acumula enganos ou vazios, pois enquanto minoria étnica dentro de um corpo nacional que a exclui, a ela não podemos associar um imaginário coletivo unívoco. Em cena do romance Sob céus estranhos, vemos a incompreensão de um funcionário português do consulado americano diante da impossibilidade para Josef de declarar a sua nacionalidade ou "raça", termo revelador da associação estreita entre o político e o biológico no cerne da concepção de pertença nacional:

- É que sou um "cinquenta-por-cento" - expliquei ao velho secretário - sou uma espécie de mulato branco. [...]

- Cinquenta por cento? ... Disparate. A alguma raça o senhor há-de pertencer, não lhe parece?

- À qual pertence o senhor? [...]

- À portuguesa - disse ele cheio de convicção [...]

- Portanto, à raça descobridora? - perguntei-lhe.

Agora ri, mas um pouco perplexo [...]

- Como o senhor deve ter verificado no questionário, nasci na Alemanha.

- É alemão, portanto.

- Ah, alemão é que não sou! Desapoderaram-me do meu passaporte.

- Sou um "cinquenta-por-cento", já lhe disse. [...] Alemão não é qualificativo de raça, mas sim de raça superior!

- Por fim aconselhou-me a pôr hebreu e eu disse:

- All right sir. Thanks sir. (Losa 1984: 45-46)

Josef, refugiado no Porto, tenta seguir caminho para os Estados Unidos, país de residência de seu irmão. Vê-se forçado, no entanto, a abandonar esse projeto em favor de Good old Man, alcunha carinhosamente atribuída ao pai, violentamente perseguido pelos nazis na Alemanha. Nesse trecho, à ideia de pureza genética, soma-se àquela de pertença a um corpo nacional como prova de existência humana. Agamben, no entanto, defende a tese de que "a relação política originária é o desterro"14 (Agamben 1997: 195), pois o poder soberano funda-se no paradoxo de uma inclusão excludente, já que ao poder proclamar um estado de exceção e suspender a validade de uma lei, o soberano se encontra à margem da própria ordem jurídica. Esse filósofo coloca, assim, em questão "toda possibilidade de situar no fundamento das comunidades políticas alguma coisa como uma 'pertença'" ${ }_{15}$ (ibidem). Essa imagem paradoxal da nação vem à tona no texto loseano quando o funcionário, a princípio seguro de sua lusitanidade, parece aperceber-se da fição sobre a qual o discurso dominante é construído: "Agora ri, mas um pouco perplexo". A questão colocada por Josef teria, assim, uma função reveladora, despertando-o para uma não-identificação com a imagem de uma suposta "raça descobridora" portuguesa, erguida sobre os escombros do passado glorioso de Portugal. 
É o desterro que sobra, portanto, como imagem solidária comum, criando entre portugueses e refugiados um fenômeno de reflexibilidade imagológica. Sobre esse processo reflexivo, Daniel-Henri Pageux explica que: "a imagem do Outro veicula também uma certa imagem de mim mesmo. Impossível evitar que a imagem do Outro [...] apareça também como a negação do Outro, o complemento, o prolongamento do meu próprio corpo, do meu próprio espaço"16 (Pageux 2007: 31).

Nesse processo, o "Eu que diz o Outro" [le Je qui dit l'Autre] constrói uma "consciência enunciativa" [conscience énonciative] (idem: 40) sobre o seu próprio lugar de enunciação. Pedro Osório encontrou em Jadwiga o álibi perfeito para a passagem ao ato de insubmissão: "Só tenho uma atitude humana - ignorar que apareceu com os passaportes. [...] Tenho de agir por mim. A maioria dos deveres que me ensinaram a cumprir são falsos. [...] as nossas fronteiras limitaram-se e passámos a consentir que nos encarcerassem numa prisão" (Redol 2017: 45-46). O protagonista compreende, assim, que o fechamento das fronteiras portuguesas aos refugiados se traduz no aprisionamento dos próprios cidadãos nacionais. Evidencia-se, ainda, que a pertença a um corpo nacional não é fruto de um desejo individual, mas do desejo soberano de um Estado-Nação que tanto desterra, quanto encarcera os seus cidadãos.

Em Sob céus estranhos, ao decidir abdicar do seu exílio americano e ficar em Portugal, Josef passa a sentir a mesma sensação de clausura descrita por Pedro Osório:

Acontece assim quando as fronteiras deste pequeno país me tocam no corpo e experimento a sensação de estar preso num cárcere feito de princípios e conceitos mesquinhos, de injustiças grosseiras [...]. Acontece quando me falta a compreensão pelos miseráveis que, numa atitude de resignação indigna, me estendem o seu sorriso servil ou a mão para uma esmola. Acontece assim quando a vida em público, decorrendo sem a presença de mulheres, me simboliza atraso, enfado, falta de espírito e de graça, e apetece-me então romper com as grades. (Losa 1984: 165)

Josef é fruto desse entre-dois representado pela imagem simbólica da fronteira. Ao adentrar nesse corpo nacional que o envolve, no qual criou amigos, amores e lutas, ele passa a sentir a opressão que sentem os portugueses, ainda que rejeite a sua resignação. $O$ verbo tocar pode, portanto, ser aqui tomado na sua dupla acepção física e afetiva. Nesse monólogo interior, vemos uma conexão profunda com a gente da sua terra de acolhimento, facto que é reforçado pelo nascimento de seu filho com Teresa, unindo numa narrativa especular os dois extremos da diegese. Josef apresenta-nos, portanto, uma pertença afetiva, despolitizada, um "saber-se que se pertence a alguém" (idem: 182). Ao fim do romance, ele faz um questionamento ontológico sobre o significado da paternidade como o fim do exílio, uma possível "chegada", a esperança de superação do trauma e de pertença a um novo corpo social: "Um filho é continuação. Ou a chegada? [...] O amor a outros seres, a continuação em outros seres, a ilusão de segurança e estabilidade ou somente uma estação intermediária na eterna fuga do homem?" (ibidem)

Pelo olhar do descendente, Blaufuks dá uma nova perspectiva à reflexão de Josef. Na sua obra, o corpo do país é representado metonimicamente pelo seu próprio corpo, enquanto 
Cadernos de Literatura Comparada

Refugiados do Holocausto em Portugal

membro português de uma linhagem de refugiados da violência nazi. As suas mãos autorretratadas segurando as fotos de seus avós são as fronteiras que os tocam à imagem da experiência afetiva vivida por Josef no romance loseano. A reflexibilidade imagológica aqui acontece entre corpos ao mesmo tempo estrangeiros e familiares, que se solidarizam enquanto "restos de Auschwitz" (Agamben 1992: 178). Como contraponto à semiótica do corpo partido, associado ao trauma do Holocausto, Blaufuks propõe aquela do corpo estendido, pronto a acolher os seus, pronto a responder a um dever de memória.

O símbolo mais pungente do caráter deontológico de sua obra é o autorretrato do avô com o dedo apontado em riste em direção ao espectador. A imagem de seu indicador pode ser compreendida como o punctum bartheano, que "parte da cena como uma flecha, e vem perfurar-me" (Barthes 1980: 49), "é este fado que, nela, me aponta (mas também que me fere, que me agarra)"17 (ibidem). Para quem Herbert aponta? Não há destinatários citados, somos todos envolvidos nessa faixa de Moebios e impelidos a responder a esse apelo ético.

Na útima página de seu álbum de retratos, descobrimos que o narrador é, também ele, um exilado, partilhando os questionamentos de Josef, que provavelmente foram outrora aqueles de seus avós: "Estranhamente, também eu, de certa forma, me tornei um exilado. Onde fica a minha casa? Não tenho bem certeza." (Blaufuks 2017: s/p). A escrita de Blaufuks é, portanto, fruto dessa "exiliência" [exiliance] (Nouss 2013: 4), enquanto condição e consciência favorável à abertura à alteridade. Essa experiência ontológica comum permitiu ressignificar a relação com a memória de seus ancestrais, de forma a ultrapassar o silêncio em torno do trauma herdado. Nesse sentido, Alexis Nouss explica que "a experiência de exílio integra a morte na vida, recusando a sua cisão. Assim, o exilado carrega a/sua morte em si"18 (idem: 12).

Mas essa consciência da morte significa, inversamente, o despertar para a vida que resta. Se Josef vê a sua continuação no corpo do filho, Blaufuks procura as suas origens naquele do avô. Direções opostas de um mesmo impulso vital: unir os "restos de Auschwitz" (Agamben 1992: 178). O álbum encerra-se por uma foto à beira-mar: nela, avô e neto avançam de costas, de mãos dadas. $O$ destino para onde caminham é incerto, mas esses corpos estão, enfim, inteiramente reconectados: símbolo maior de um compromisso pós-memorial firmado.

\section{Conclusão}

Como ponto comum da escrita das três obras de pendor autobiográfico analisadas - O cavalo espantado (1960) de Alves Redol, Sob céus estranhos (1962) de Ilse Losa e Sob céus estranhos: uma história de exílio (2007) de Daniel Blaufuks -, encontra-se um forte dever de memória com relação ao relato da passagem de refugiados do Holocausto por terras lusitanas. Todos esses autores possuem uma relação pessoal com esse episódio histórico, projetada no universo ficcional de forma mais ou menos explícita através de seus protagonistas, os quais encarnam, respectivemente, a figura do "Justo entre as Nações", ${ }^{19}$ a do refugiado judeu em solo português, e aquela do descendente de refugiados.

No romance de Redol, o uso da terceira pessoa do singular permite um distanciamento dos fatos propício à autoanálise crítica. Além disso, a imagem da instância autoral mantém-se pro- 
tegida por detrás do nome e das ações do personagem. No entanto, a existência de um prólogo em primeira pessoa, no qual o autor afirma conhecer Pedro Osório no espaço extra-diegético, cria uma "paratopia" (Maingueneau 2004: 52-53), insinuando ao leitor uma relação entre autor, narrador e personagem. Essa ambiguidade criada entre distanciamento e proximidade permite a construção de um espaço de envolvimento coletivo, de partilha social do conflito ético vivido por Pedro Osório.

No romance de Losa, por sua vez, ainda que a voz narrativa assuma, inicialmente, uma postura de distanciamento e de proteção, representada pelo uso da terceira pessoa do singular, ela adquire, posteriormente, o tom íntimo de um fluxo de pensamento provocado pela erupção das "memórias subterrâneas" de Josef (Pollak 1993: 18), carregadas da violência da qual foi vítima na Alemanha. Em Losa, a relação entre autor, narrador e personagem pode ser estabelecida, portanto, no momento da passagem da voz narrativa para a primeira pessoa do singular, trazendo consigo elementos biográficos autorais.

Assim, enquanto que em Redol temos uma autoanálise crítica tanto do sujeito quanto da sociedade, associada a um apelo à escuta dos testemunhos do período histórico da Segunda Guerra como meio de formação social; o texto de Losa apresenta um viés psicanalítico, uma necessidade íntima de contar, voltada, sobretudo, para a reconstrução de si. Na "autobiografia pós-memorial" de Blaufuks um pacto autobiográfico é estabelecido com o leitor desde a primeira página, apelando a um envolvimento tanto ético, quanto afetivo, rompendo as barreiras entre interior e exterior, individual e coletivo. Nela, a voz narrativa conta-se ao contar a história de outros seres, que juntos contribuem à polifonia de vozes da História do Holocausto em Portugal.

O efeito polifónico desejado por Blaufuks é criado já a partir do título de seu livro, denotando uma profunda identificação com a trajetória humana e o legado literário de Ilse Losa. Ao narrar a sua própria vida, Blaufuks procura uma resposta aos questionamentos deixados em suspensão pelo personagem loseano Josef, unindo os cacos da "pátria cultural" partida por meio de uma "cadeia paratópica" de enunciação. O autor mostra-nos, assim, que o trauma constitutivo e fundador expresso por esse personagem é transmitido transgeracionalmente. A construção de Blaufuks como sujeito implica, portanto, a aceitação e a ressignificação da dor - simultaneamente pessoal e coletiva - transmitida pelos seus avós maternos Ursel e Herbert August. Mas essa construção passa, também, por uma experiência de "exiliência" comum. Eis a faixa de Moebios blaufukseana.

Há, ainda, nas três obras analisadas, um consenso sobre a importância do papel dos refugiados do Holocausto para a criação de um espaço psicossocial de reflexão sobre o ser português, através do olhar construído sobre o Outro. Assim, dois tipos imagológicos atribuídos aos refugiados pelos portugueses sobrevêm da leitura dessas obras: o "ideológico" e o "utópico" (Moura 1998: 51). Valendo-se do discurso hegemónico ou contrapondo-se a ele de forma idealizada, o refugiado é visto com "desconfiança" ou "inveja" (Blaufuks 2007: s/p). Ora descritos como pessoas "com desembaraço", ora como "gente estranha" (Losa 1984: 62), a figura do refugiado é dificilmente apreendida na complexidade da sua identidade compósita e da sua 
Cadernos de Literatura Comparada

Refugiados do Holocausto em Portugal

condição de apátrida. Se os narradores autodiegéticos de Blaufuks e Losa assumem o papel de "tradutores culturais" (Hall 2008: 396), restituindo a humanidade dessas minorias vítimas de um estado de exceção, Redol idealiza-as como símbolo da não-pertença ao Estado hegemónico.

Ao abalar os paradigmas do discurso identitário nacional construído através de um biopoder, as refugiadas são retratadas pelos três autores como um elemento alóctone especialmente perturbador. Em todas as narrativas, temos ainda um fenômeno semelhante de "reflexibilidade imagológica" (Pageux 2007: 141) por meio do qual a figura do refugiado permite-nos pensar num desterro simbólico partilhado, uma vez revelada a relação de inclusão excludente sobre a qual se funda a soberania.

Por oposição a uma pertença jurídico-política fictícia, uma vez que "a relação política originária é o desterro" (Agamben 1997: 195), os escritores estudados propõem uma pertença afetiva, despolitizada, um "saber-se que se pertence a alguém" (Losa 1984: 182). Tal pertença é a base para o respeito ao dever de memória com relação a essas "vidas nuas" (Agamben 2002: 31), o recolher dos "restos de Auschwitz" (Agamben 1992: 178) deixados em terras lusitanas: Pedro Osório através do amor por Jadwiga; Josef Berger por Teresa e pelo filho português; Daniel Blaufuks pelo retorno simbólico aos braços do avô, no lar comum construído em Portugal. Relatar as suas histórias pessoais parece ser, simultaneamente, a única forma de responder a um dever de memória para com os portugueses sobre a história do país durante esse período.

\section{NOTAS}

* Karina Marques é professora na Universidade de Poitiers, França. Seus estudos em Literatura Brasileira e Portuguesa centram-se na área de literatura de exílio, com interesse particular sobre o período da Segunda Guerra Mundial. Doutorou-se em Literatura Brasileira e Portuguesa comparada pela Universidade Sorbonne Nouvelle - Paris 3 com uma tese sobre as obras de Ilse Losa e Samuel Rawet. Editou em 2018 a correspondência de Ilse Losa: Ilse Losa: estreitando laços. A correspondência com os pares lusófonos (1948-1999), Porto, Afrontamento. Última publicação: (2021), "La correspondance d'Ilse Losa avec ses pairs lusophones (1948-1999) : engagement, construction auctoriale et enjeux archivistiques", Reflexos [En ligne], n ${ }^{\circ} 5$, Engagement et désengagement dans les littératures et les arts des pays lusophones: l'archive, le manuscrit, <http://revues.univ-tlse2.fr/reflexos/index.php?id=792> (último acesso em: 17/12/2021).

${ }^{1}$ Segundo Lochery, "o relatório da PVDE - a polícia secreta portuguesa, responsável pelo controlo das fronteiras portuguesas - refere da seguinte forma o número total de refugiados da Europa inteira que entraram em Portugal em 1940: 30 854 entradas por terra, 6843 por mar e 5843 por ar, perfazendo um total de 43540 entradas." (Lochery 2012: 58). Pimentel afirma que 
"segundo as estatísticas oficiais portuguesas, entraram em Portugal, em 1940, mais de 38000 estrangeiros e saíram do país cerca de 36 000, números, mais uma vez, reveladores de que a estadia era curta. [...] Lembre-se, porém, que se incluem neste número apenas os que entravam legalmente, e não os clandestinos, além de que, embora a maioria dos estrangeiros fosse constituída por refugiados, também havia, entre eles, cidadãos de países neutros ou mesmo da Alemanha, que não estavam em fuga. [...] O Joint (JDC, American Joint Jewish Distribution Committee) assinalou que, entre junho de 1940 e maio de 1941, passaram pelo país cerca de 40000 pessoas, um número que se aproximava dos 42000 refugiados pela Comassis [Comissão de Assistência aos Refugiados Judeus em Portugal]" (Pimentel 2006: 119-120). Daniel Blaufuks diz, ainda, que "das cinquenta a duzentas mil pessoas que passaram por Lisboa, apenas cinquenta aqui ficaram" (Blaufuks 2007: s/p).

${ }^{2}$ llse Losa escreveu apenas um livro em alemão: (1967) Das versunkene Schiff. Erzählungen, Berlim, Verlag der Nation [O barco afundado, 1979]. Suas principais obras escritas em português e traduzidas, posteriormente, para alemão são: (1990) Die Welt in der ich lebte, Maralde Meyer-Minnemann (trad.), Friburgo, Beck \& Glückler [O mundo em que vivi, 1949]; (1991) Unter fremden Himmeln, Ilse Losa (trad.), Friburgo, Beck \& Glückler [Sob céus estranhos, 1962]; (1992) Tagträume und Erzählungen der Nacht, Elfriede Engelmayer e Gesa Hasenbrink (trad.), Friburgo, Beck \& Glückler [na tradução literal Devaneios e contos da noite, correspondendo à coletânea de contos Caminhos sem destino, 1991]. A novela Retta ou os ciúmes da morte (1958) foi publicada na revista literária Neue Deutsche Literatur (1952-2004) da RDA, no mesmo ano em que saiu no mercado editorial português. Losa traduziu, ainda, a obra do escritor português Manuel da Fonseca: (1990) Saat des Windes, Friburgo, Glückler [Seara de vento, 1958]. E organizou, juntamente com outros intelectuais portugueses, antologias de contos e poemas da literatura portuguesa, publicadas na Alemanha: Lopes, Óscar/ Losa, Ilse (1962), Portugiesische Erzähler, Berlim, Aufbau-Verlag; Lopes, Oscar/ Losa, Ilse (1969), Ich kann die Liebe nicht vertagen - Gedichte - Moderne portugiesische Lyrik - 1, Berlim, Verlag Volk und Welt; Gonçalvez, Egito/ Lopes, Óscar/ Losa, Ilse (1973), Erkundungen : 30 portugiesische Erzähler, Berlim, Verlag Volk und Welt.

${ }^{3}$ Tradução nossa (Tn): "Estado-Nação significa: Estado que faz da natividade, do nascimento (quer dizer, da pura e simples vida humana) o fundamento da sua soberania" [l'État-nation signifie : État qui fait de la nativité, de la naissance (c'est-à-dire de la pure et simple vie humaine) le fondement de sa souveraineté] (Agamben 2002: 31).

4 Tn: "dando lugar ao outro" [faisant place à l'autre] (Chiantaretto 2002: 14)/ "ao mesmo tempo múltiplas pertenças e o solo comum da pertença humana" [tout à la fois de multiples appartenances et le sol commun de l'appartenance humaine] (Chiantaretto 2002: contracapa).

5 Tn: "outras 'postagens' e o seu intervalo de tempo, alinhando-se à prática de citação e mediação que as caracteriza [...] oscilação incômoda entre continuidade e ruptura." [other "posts" and their belatedness, aligning itself with the practice of citation and mediation that characterize them [...] uneasy oscillation between continuity and rupture] (Hirsch 2008: 106).

${ }^{6} \mathrm{Tn}$ : “com a vida e a morte, com o tempo e a eternidade, envolvidos numa faixa de Moebios do coletivo e do individual" [with life and death, with time and eternity, enveloped in a Möbius strip of the collective and the individual] (Hirsch 1992: 8).

${ }^{7}$ Tn: "o resto de Auschwitz - as testemunhas - não são nem os mortos, nem os sobreviventes [...] mas o que resta entre eles [...] significa precisamente a impossibilidade de coincidir para o todo e para a parte" [le reste d'Auschwitz - les témoins n'est ni les morts ni les survivants [...] mais ce qui reste entre eux [...] signifie précisément l'impossibilité pour le tout et pour la partie de coïncider] (Agamben 1992: 178).

${ }^{8} \mathrm{Tn}$ : "não eram somente os censores portugueses que supervisionavam a imprensa; a legação alemã estudava de perto cada linha escrita a fim de assegurar que ela não continha nenhuma crítica sobre a ocupação". [Ce n'étaient pas seulement les censeurs portugais qui surveillaient la presse ; la légation allemande étudiait de près chaque ligne écrite afin de s'assurer qu'elle ne contenait aucune critique de l'occupation] (Meneses 2015: 9).

${ }^{9}$ O jornal português (1938-1951), jornal de propaganda governamental, era exibido nos cinemas antes das sessões habituais, 


\section{Cadernos de Literatura Comparada \\ Refugiados do Holocausto em Portugal}

cada número tendo duração aproximada de 10 minutos. Foi produzido pela SPAC (Sociedade portuguesa de atualidades cinematográficas) para o SPN (Secretariado da propaganda nacional) criado em 1933, passando a chamar-se SNI (Secretariado nacional da informação), em 1944.

${ }^{10}$ Tn: "um conceito cultural, ou seja, inteligível a partir do esforço humano para valorizar a vida" [un concept culturel, c'est-à-dire intelligible à partir de l'effort humain pour valoriser la vie] (De Martino 2016: 397).

${ }^{11} \mathrm{Tn}$ : "um conceito-limite que coloca radicalmente em crise os fundamentos do Estado-Nação, abrindo espaço, simultaneamente, a novas categorias conceituais" [un concept-limite qui met radicalement en crise les fondements de l'État-nation et, en même temps, ouvre le champ à des nouvelles catégories conceptuelles] (Agamben 2002: 34).

${ }^{12} \mathrm{Tn}$ : "os valores fundamentais do grupo sobre a alteridade" [les valeurs fondamentales du groupe sur l'altérité] (Moura 1998: 51)/ "tem uma função de subversão dos valores do grupo" [ont une fonction de subversion des valeurs du groupe] (idem: 52). ${ }^{13} \mathrm{Tn}$ : "ao quebrar a identidade entre homem e cidadão [...] coloca em crise a ficção originária da soberania" [en cassant l'identité entre homme et citoyen [...] il met en crise la fiction originaire de la souveraineté] (Agamben 2002: 32). ${ }_{14}$ Tn: "a relação política originária é o desterro" [La relation politique originaire est le ban] (Agamben 1997: 195).

${ }^{15} \mathrm{Tn}$ : "toda possibilidade de situar no fundamento das comunidades políticas alguma coisa como uma 'pertença'" [toute possibilité de placer au fondement des communautés politiques quelque chose comme une "appartenance"] (ibidem).

${ }^{16} \mathrm{Tn}$ : "a imagem do Outro veicula também uma certa imagem de mim mesmo. Impossível evitar que a imagem do Outro [...] apareça também como a negação do Outro, o complemento, o prolongamento do meu próprio corpo, do meu próprio espaço". [l'image de l'Autre véhicule aussi une certaine image de moi-même. Impossible d'éviter que l'image de l'Autre [...] n'apparaisse aussi comme la négation de l'Autre, le complément, le prolongement de mon propre corps et de mon propre espace] (Pageux 2007: 31).

17 Tn : "parte da cena como uma flecha, e vem perfurar-me" [qui part de la scène, comme une flèche, et vient me percer] (Barthes 1980: 49)/ "é este fado que, nela, me aponta (mas também que me fere, que me agarra)" [c'est ce hasard qui, en elle, me point (mais aussi me meurtrit, me poigne)] (ibidem).

18 Tn: "a experiência de exílio integra a morte na vida, recusando a sua cisão. Assim, o exilado carrega a/sua morte em si" [l'expérience exilique intègre la mort dans la vie, refusant leur césure. Ainsi, l'exilé porte la/sa mort en lui] (Nouss 2013: 12). 19 A expressão "Justo entre as Nações" (em hebraico: מלועה תומוא ידיסח, Chasidei Umot HaOlam) foi tirada da tradição judaica, da literatura dos Sábios, onde é usada para descrever não-judeus que vinham em auxílio do povo judaico em tempos de necessidade, ou não-judeus que respeitam os princípios básicos estabelecidos na Bíblia, incluindo a proibição de derramamento de sangue.Trata-se igualmente de um título honorífico concedido pelo Yad VaShem, o Memorial do Holocausto em Israel, como reconhecimento a todos os não-judeus que durante a II Guerra Mundial não apenas salvaram judeus, mas arriscaram a sua vida ao fazê-lo. Quatro portugueses (Aristides de Sousa Mendes, Carlos Sampaio Garrido, José Brito Mendes e o padre Joaquim Carreira) foram agraciados com esse título. 


\section{Bibliografia}

Afonso, Rui Afonso (1995), Um bom homem. Aristides Sousa Mendes, o "wallenberg português". Lisboa, Editorial Caminho.

Agamben, Giorgio (1992), Ce qui reste d'Auschwitz. Paris, Éditions Payot \& Rivages.

- (1997), Homo Sacer. Le pouvoir souverain et la vie nue. Paris, Seuil.

-- (2002), Moyens sans fins. Paris, Rivages.

Anderson, Benedict (1996), L'imaginaire national. Réflexions sur l'origine et l'essor du nationalisme. Paris, La Découverte.

Bakhtin, Mikhaïl (1978), Esthétique et théorie du roman. Paris, Gallimard.

Barthes, Roland (1980), La chambre claire. Note sur la photographie. Paris, Le Seuil.

Bhabha, Homi (2007), Les lieux de la culture. Une théorie postcoloniale. Paris, Éditions Payot et Rivages.

Blaufuks, Daniel (2007), Sob céus estranhos. Uma história de exílio. Lisboa, Tinta-da-China.

Chalante, Susana (2011), "O discurso do Estado salazarista perante o "indesejável" (19331939)", Análise Social, vol. XLVI, nº 198, Universidade de Lisboa-Instituto de Ciências Sociais: 41-63.

Chiantaretto, Jean-François (2002), L'Écriture de soi peut-elle dire l'histoire ?. Paris, Bpi/ Centre Pompidou.

De Martino, Ernesto (2016), La fin du monde. Essai sur les apocalypses culturelles. Paris, Éditions EHESS.

Ferreira, Ana Paula (2012), "Para a história do neo-realismo: O cavalo espantado, testemunho ético-poético", Nova Sintese. Textos e contextos do neo-realismo, no 7, Colibri, 61-71.

Ferro, António (2003), Entrevista de António Ferro a Salazar, Lisboa, Parceria A. M. Pereira Livraria Editora.

Hall, Stuart (2008), Identités et cultures. Politiques des “Cultural Studies”, Paris, Éditions Amsterdam.

Hirsch, Marianne (1992-1993), "Family Pictures: Maus, Mourning, and Post-Memory", Discourse, vol. 15, $\mathrm{n}^{0} 2$, Wayne State University Press: 3-29.

-- (2008), "The Generation of Postmemory", Poetics Today, $\mathrm{n}^{0} 29$, Wayne State University Press, 103-128.

Lochery, Neil (2012), A guerra nas sombras da cidade da luz, 1939-1945, Lisboa, Editorial Presença [War in the Shadows of the City of Light, 1939-1945, 2011].

Losa, Ilse (1984), Sob céus estranhos, Porto, Afrontamento [1962].

Maingueneau, Dominique (2004), Le discours littéraire. Paratopie et scène d'énonciation, Paris, Armand Colin.

Maranhão, Tiago (2006), Os indesejáveis. Políticas de migração no contexto da Segunda Guerra Mundial: uma análise comparativa entre Portugal e Brasil [tese de mestrado], Lisboa, Universidade de Lisboa-Instituto de Ciências Sociais. 
Marques, Ana Isabel (2019), "Imagens de Portugal no romance Sob céus estranhos de Ilse Losa", in De passagem: artistas de língua alemã no exílio português, Porto, Edições Afrontamento e Instituto de Literatura Comparada Margarida Losa: 47-64.

Marques, Karina (2017), "Identité nationale et identité genrée: le genre en tant que construction du pouvoir chez Ilse Losa", in Écritures migrantes du genre. Croiser les théories et les formes littéraires en contextes comparés. Paris, Honoré Champion, 97-105.

Meneses, Filipe Ribeiro de (2015), "Salazar face à la Shoah", Revue d'Histoire de la Shoah, no 203, Mémorial de la Shoah: 255-276.

Milgram, Avraham (1999), "Portugal, the consuls, and the jewish Refugees, 1938-1941", Yad Vashem Studies, vol. XXVII, KTAV Publishing House: 123-56.

Moura, Jean-Marc (1998), "L'image de l'étranger: perspectives des études d'imagologie littéraire", in Europe littéraire et l'ailleurs. Paris, Presses Universitaires de France: 35-55.

Mühlen, Patrick von zur (1992), Fluchtweg Spanien-Portugal: Die Deutsche Emigration und der Exodus aus Europa 1933- 1945. Bonn, J.H.W. Dietz.

Nascimento, Lyslei/ Kirschbaum, Saul (2019), "Sob céus estranhos: Ilse Losa e Daniel Blaufuks", Arquivo Maaravi, v. 13, n. 24, UFMG, 89-112.

Ninhos, Cláudia (2017), Portugal e os nazis. Lisboa, A Esfera dos Livros.

Ninhos, Cláudia / Pimentel, Irene Flunser (2013), "Salazar, Portugal e o Holocausto", Lisboa, Temas e Debates.

Nora, Pierre (1984), "Entre mémoire et histoire, la problématique des lieux", in Les lieux de mémoire, I. La République, Paris, Gallimard, XVI-XLII.

Nuselvici (Nouss), Alexis (2013), "Exiliance: condition et conscience", FMSH-WP, no 44, Fondation Maison des Sciences de l'Homme: 1-15.

Pageux, Daniel-Henri (2007), Littératures et cultures en dialogue. Paris, L'Harmattan.

Pimentel, Irene Flunser (2006), Judeus em Portugal durante a Segunda Guerra Mundial. Em fuga a Hitler e ao Holocausto. Lisboa, A Esfera dos Livros.

Pollak, Michael (1993), Une identité blessée. Paris, Éditions Métailié.

Redol, Alves (2017), O cavalo espantado. Lisboa, Caminho [1960].

Ricœur, Paul (1984), Temps et récit 2. La configuration dans le récit de fiction. Paris, Éditions du Seuil.

Seixas, Maria João (s/d), "Conversa com vista para", Daniel Blaufuks, <http://www. danielblaufuks.com/webmac/extras/seixas.html> (último acesso em 10/05/2021).

Schäfer, Ansgar (1992), "Obstáculos no caminho para a liberdade", Aspectos e Tendências de Estudos Germanísticos em Portugal. Instituto Alemão: 85-94.

Vogt, Jochen (2019), "Exílio em Portugal - estudos sobre o exílio na República Federal da Alemanha. Reflexões de um germanista alemã", in De passagem: artistas de língua alemã no exílio português. Porto, Editora Afrontamento e Instituto de Literatura Comparada Margarida Losa: 13-35. 